\title{
Factors affecting the performance of Pantaneiro horses
}

\section{Geraldo da Silva e Souza ${ }^{1}$, Eliane Gonçalves Gomes ${ }^{1 *}$, Sandra Aparecida Santos ${ }^{2}$, Adalgiza Souza Carneiro de Rezende ${ }^{3}$, Débora Roque de Freitas Andrade ${ }^{4}$, Márcia Furlan Nogueira ${ }^{2}$, Pablo Trigo ${ }^{5}$, Urbano Gomes Pinto de Abreu²}

\author{
${ }^{1}$ Embrapa, Secretaria de Gestão e Desenvolvimento Institucional, Brasilia, DF, Brazil. \\ 2 Embrapa Pantanal, Corumbá, MS, Brazil. \\ ${ }^{3}$ Universidade Federal de Minas Gerais, Escola de Veterinária, Departamento de Zootecnia, Belo Horizonte, MG, Brazil. \\ ${ }^{4}$ Universidade Federal de Minas Gerais, Programa de Pós-graduação em Zootecnia, Belo Horizonte, MG, Brazil. \\ ${ }^{5}$ Universidad Nacional de La Plata, Facultad de Ciencias Veterinarias, La Plata, Provincia de Buenos Aires, República Argentina.
}

\begin{abstract}
This study aimed to assess the physical performance of Pantaneiro horses with and without equine infectious anemia (EIA) under functional conditions of cattle management. The horses were subjected to a performance test and split into two groups according to a completely randomized design: animals were chosen from populations testing positive and negative for EIA. Performance was measured as a function of a data envelopment analysis (DEA) model considering four outputs and one unitary input. The output measures were the distance achieved in the performance test, hematocrit as a weighted average over the test duration, respiratory rate as weighted average over the test duration, and the level of lactic acid at the test termination. Weights for the hematocrit and the respiratory rate output variables were determined by means of factor analysis. The performance score was a weighted average of the output variables with the weights defined by the averages of the optimum individual multipliers in the DEA analysis. Contextual variables of interest were age, horse weight, room temperature, and corporal temperature. Only groups and room temperature were statistically significant effects, as indicated by a bootstrap analysis. The performance of group positive for EIA is significantly lower than that of the group negative for EIA and room temperature has a negative effect.
\end{abstract}

Key Words: covariance analysis, data envelopment analysis, equine infectious anaemia, experimental design, multivariate analysis

\section{Introduction}

The Pantanal wetland in the central western region of Brazil (Pantanal for short) counts 9.63 million heads of cattle according to the 2015 Brazilian county livestock research. This livestock is of economic importance in this region. The use of the so-called Pantaneiro horses is critical for the appropriate management of cattle. Equines were brought to Brazil by the first European settlers and in the Pantanal, they have grown and multiplied without human interference for more than two centuries, giving rise to the Pantaneiro breed (Santos et al., 2016).

In recent years, the occurrence of equine infectious anemia (EIA) has become a serious drawback for the use of Pantaneiro horses in cattle management (Oliveira

Received: June 12, 2017

Accepted: September 23, 2017

*Corresponding author: eliane.gomes@embrapa.br

Copyright (C) 2018 Sociedade Brasileira de Zootecnia. This is an Open Access article distributed under the terms of the Creative Commons Attribution License (http://creativecommons.org/licenses/by/4.0/), which permits unrestricted use, distribution, and reproduction in any medium, provided the original work is properly cited. et al., 2011). Equine infectious anemia is an incurable and transmissible viral disease affecting equines (Craigo and Montelaro, 2008; Cook et al., 2009). It is endemic in the Pantanal and vaccines are not available to control the disease. The infected horses have their working capacity reduced or, if asymptomatic, may be a permanent source for the spread of the disease (Juliano et al., 2016).

Pantaneiro horses are generally not euthanized if they test positive for EIA. According to a Brazilian government web page, euthanasia is not required in endemic regions (Brasil, 2004). This fact leads to the investigation of whether infected horses perform satisfactorily when used in cattle management (Rezende et al., 2016). A growing number of cattle raisers use Pantaneiro horses in cattle management and are showing increased concern regarding this issue.

This study aimed to assess the physical performance of horses with and without EIA under functional conditions of cattle management. To this end, 16 male equines, equally split into two groups - EIA positive and EIA negative - were evaluated after a stress test. The performance was determined by multivariate methods and by data envelopment analysis (DEA) models with unitary inputs and further analyzed 
by nonparametric and bootstrap regression methods. The concept of DEA appears in the literature in the study of performance of decision-making units in a broader context. Decision-making units may be firms, schools, hospitals, airplane companies, farmers, or experimental units arranged according to an experimental design. Particularly in experimental design, the use of DEA is not new. Marlin and Sohn (2016) proposed a hybrid process that combines simulation, design of experiments, and DEA to study an educational system. Yang et al. (2016) applied DEA and design of experiment concepts to evaluate the emission of water pollutants. Leme et al. (2014) proposed a simulation approach based on the philosophy of design of experiments to test the impact of environmental variables on the DEA efficiency scores of Brazilian electricity companies. Grigoroudis et al. (2014) proposed a DEA model and optimal design to investigate biomass supply chain networks. Liu and Yang (2014) used DEA to obtain a robust design for the analysis of carbon filters. Gutiérrez and Lozano (2010) and Miranda et al. (2017) combined Taguchi's method (orthogonal arrays) and DEA to estimate the response of experimental units. Bezerra Neto et al. (2007, 2010, 2012) and Lima et al. (2014) used DEA models to evaluate the performance of intercropping production systems arranged according to different experimental designs. Gomes et al. (2008) proposed the use of DEA efficiency scores, with unitary input, in the multivariate analysis of variance. They discussed two examples of intercropping systems, where the experimental plots were arranged according to specific designs. The authors stated that this approach agrees with the standard analysis of variance (covariance) for univariate responses and simplifies the statistical analysis in the multivariate case.

The approach proposed here differs from the use of classical techniques, as for instance in Rezende et al. (2016). We borrowed the notion of performance from operational research, in which it is defined as a solution of optimization problems associated with production functions. Our view of performance is in close association with DEA, in a multicriteria decision analysis context (Gomes et al., 2008).

\section{Material and Methods}

The experimental design was completely randomized, with the choice of eight animals per treatment. Initial conditions of the animals differed. The following response variables were measured: lactic acid blood concentration, hematocrit (initial condition, immediately after the test, and 10,30, and $60 \mathrm{~min}$ after the test), heart rate at four time periods, respiratory rate at three time periods, and distance achieved in the test. Contextual variables of interest were room temperature, horse age, horse weight, and horse superficial temperature (this is skin temperature measured in 11 different parts of the animal body, determined by a thermal imaging camera).

The objective of the statistical analysis was to compare the treatment effects (positive and negative for EIA), adjusted for the covariates. Having the same number of experimental units per treatment is a common choice in experimental design, which facilitates the consideration of type II probability errors in the design (Scheffé, 1959) and allows the same precision for the estimate of each treatment effect. As a performance vector, we initially considered a five-dimensional output vector with these components: distance achieved, lactic acid concentration, hematocrit score, heart rate score, and respiratory rate score (Tables 1 and 2). Later, the heart rate score was eliminated, given its negative rank correlation with distance and very low association with the remaining performance variables. Statistical methods considered here were descriptive statistics, standard nonparametric analysis with the use of ranks, standard multivariate analysis of variance, factor analysis, and regression analysis. Performance analysis is a modification of standard DEA models. We briefly summarize below only the most important topics for our analyses: multivariate factor analysis and DEA models assuming a unitary input.

Mardia et al. (1980) and Johnson and Wichern (2007) were referenced for the factor analysis. A vector of a $p$-dimension variable $x$ with mean $\mu$ and variance-covariance matrix $\Omega$ satisfies the $k$-factor model if $x-\mu=\Lambda f+u, \Lambda=\left(\lambda_{i j}\right)$ is a $p \times k$ matrix of constants. $f(k \times 1)$ and $u(p \times 1)$ are random. The common factors are the components of $f$. The components of $u$ are the specific factors. The variancecovariance matrix of $u$ is given by $\Phi=\operatorname{diag}\left(\varphi_{11}, \ldots, \varphi_{p p}\right)$. We then have $x_{i}-\mu_{i}=\sum_{j=1}^{k} \lambda_{i j} f_{j}+u_{i}$.

Under the factor model, the variance $\sigma_{i}^{2}$ of $x_{i}$ is given by $\sigma_{i}^{2}=\sum_{j=1}^{k} \lambda_{i j}^{2}+\varphi_{i i}$. The term $h_{i}^{2}=\sum_{j=1}^{k} \lambda_{i j}^{2}$ is called communality and represents the variance of $x_{i}$ that is shared with the other variables via the common factors. $\lambda_{i j}=\operatorname{Cov}\left(x_{i}, f_{j}\right)$ is the extent to which $x_{i}$ depends on the $j$-th common factor.

The performance response score of horse $i$ on the marginal dimension $d$ of the output vector based on the $k$-factor model is defined, in our application, by a weighted average. The weights are the relative communalities as defined in (1). These scores differ from usual factor scores 
and endow the weighting system with robustness relative to orthogonal transformations of the factor model.

$$
y_{i}^{d}=\sum_{j=1}^{v} \theta_{j d} c_{j}^{i d}, \theta_{j d}=h_{j d}^{2} / \sum_{\tau=1}^{v} h_{\tau d}^{2}
$$

Data envelopment analysis models are defined by linear programming problems designed to measure performance under production assumptions or for benchmarking purposes. It is possible to consistently estimate a production function using DEA responses. Intuitively, a DEA measure estimates the maximum increase in production that can be achieved given input levels (see Cooper et al. (2011) for details about DEA modeling). In our application, the output-oriented notion is generalized to measure output performance when a vector of responses is characterized by marginal indicators. We assume unitary input for all experimental units to make the analysis consistent. This idea is not unusual in the DEA literature and can be seen, for instance, in Caporaletti et al. (1999), Lovell and Pastor (1999), De Koeijer et al. (2002), Leta et al. (2005), and Gomes et al. (2008, 2012).

In DEA modeling, it is necessary to define the units under evaluation - decision-making units - and the production variables (inputs and outputs). In an experimental design, the experimental units arranged according to the layout of the design are the decision-making units. The output vector is the non-negative response vector of each experimental unit. The issue under consideration is the

Table 1 - Experimental data - response variables

\begin{tabular}{|c|c|c|c|c|c|c|c|c|c|c|c|c|c|c|c|}
\hline \multirow{2}{*}{$\begin{array}{l}\text { Experimental } \\
\text { unit }\end{array}$} & \multirow{2}{*}{ Treatment } & \multirow{2}{*}{$\begin{array}{c}\text { Lactic } \\
\text { acid } \\
(\mathrm{mmol} / \mathrm{L})\end{array}$} & \multirow{2}{*}{$\begin{array}{l}\text { Distance } \\
(\mathrm{km})\end{array}$} & \multicolumn{5}{|c|}{$\begin{array}{c}\text { Hematocrit } \\
(\%)\end{array}$} & \multicolumn{4}{|c|}{$\begin{array}{c}\text { Heart rate } \\
\text { (beats per minute) }\end{array}$} & \multicolumn{3}{|c|}{$\begin{array}{c}\text { Respiratory rate } \\
\text { (breaths per minute) }\end{array}$} \\
\hline & & & & $\mathrm{H} \_r$ & H_o & $\mathrm{H}_{-} 10$ & H_30 & H_60 & $\mathrm{CF}_{-} \mathrm{r}$ & $\mathrm{CF}_{-} 1$ & CF_2 & $\mathrm{CF}_{-} \mathrm{f}$ & $\mathrm{RF}_{-} \mathrm{r}$ & $\mathrm{RF} \_2$ & $\mathrm{RF}_{-} \mathrm{f}$ \\
\hline $1 \mathrm{P}$ & $\mathrm{P}$ & 8.8 & 5.3 & 35 & 39 & 33 & 38 & 27 & 40 & 57 & 172 & 192.0 & 12 & 36 & 50.0 \\
\hline $2 \mathrm{P}$ & $\mathrm{P}$ & 10.7 & 6.0 & 34 & 42 & 34 & 35 & 29 & 40 & 101 & 149 & 205.0 & 12 & 56 & 88.0 \\
\hline $3 P$ & $\mathrm{P}$ & 4.8 & 3.9 & 27 & 27 & 27 & 21 & 24 & 38 & 69 & 172 & 172.0 & 16 & 56 & 56.0 \\
\hline $4 P$ & $\mathrm{P}$ & 17.2 & 5.2 & 28 & 34 & 29 & 28 & 28 & 37 & 100 & 111 & 158.0 & 16 & 52 & 72.0 \\
\hline $5 \mathrm{P}$ & $\mathrm{P}$ & 11.0 & 5.3 & 29 & 39 & 30 & 28 & 23 & 37 & 75 & 148 & 208.0 & 30 & 40 & 64.0 \\
\hline $6 \mathrm{P}$ & $\mathrm{P}$ & 6.1 & 4.0 & 32 & 40 & 35 & 32 & 25 & 45 & 106 & 202 & 202.0 & 20 & 56 & 56.0 \\
\hline $7 \mathrm{P}$ & $\mathrm{P}$ & 4.9 & 3.9 & 22 & 32 & 28 & 25 & 25 & 46 & 97 & 197 & 197.0 & 32 & 64 & 64.0 \\
\hline $8 \mathrm{P}$ & $\mathrm{P}$ & 5.3 & 3.9 & 33 & 34 & 30 & 30 & 29 & 38 & 96 & 167 & 167.0 & 30 & 56 & 56.0 \\
\hline $1 \mathrm{~N}$ & $\mathrm{~N}$ & 8.4 & 4.3 & 25 & 41 & 35 & 30 & 27 & 48 & 110 & 144 & 144.0 & 52 & 64 & 64.0 \\
\hline $2 \mathrm{~N}$ & $\mathrm{~N}$ & 19.8 & 5.3 & 26 & 45 & 31 & 30 & 25 & 50 & 74 & 178 & 178.0 & 48 & 96 & 84.0 \\
\hline $3 \mathrm{~N}$ & $\mathrm{~N}$ & 12.5 & 5.8 & 27 & 39 & 33 & 29 & 28 & 48 & 105 & 210 & 210.0 & 32 & 80 & 76.0 \\
\hline $4 \mathrm{~N}$ & $\mathrm{~N}$ & 8.1 & 5.8 & 25 & 41 & 32 & 29 & 42 & 48 & 92 & 130 & 130.0 & 30 & 53 & 53.0 \\
\hline $5 \mathrm{~N}$ & $\mathrm{~N}$ & 2.3 & 6.9 & 28 & 46 & 40 & 35 & 31 & 54 & 85 & 157 & 192.0 & 25 & 56 & 72.0 \\
\hline $6 \mathrm{~N}$ & $\mathrm{~N}$ & 17.8 & 5.4 & 34 & 44 & 40 & 35 & 35 & 54 & 85 & 204 & 204.0 & 28 & 60 & 60.0 \\
\hline $7 \mathrm{~N}$ & $\mathrm{~N}$ & 14.5 & 5.4 & 27 & 41 & 35 & 29 & 24 & 40 & 85 & 130 & 130.0 & 36 & 80 & 64.0 \\
\hline $8 \mathrm{~N}$ & $\mathrm{~N}$ & 10.2 & 5.6 & 27 & 40 & 33 & 31 & 32 & 52 & 105 & 161 & 161.0 & 36 & 60 & 84.0 \\
\hline
\end{tabular}

$\mathrm{P}$ - testing positive for EIA; $\mathrm{N}$ - testing negative for EIA; $\mathrm{H} \_\mathrm{r}$ - hematocrit when resting; $\mathrm{H} \_0$ - hematocrit immediately after the stress test; $\mathrm{H} \_10$ - hematocrit 10 min after the stress test; H 30 - hematocrit 30 min after the stress test; H 60 - hematocrit 60 min after the stress test; CF $\mathrm{r}$ - heart rate when resting; CF 1 - heart rate at time 1; CF 2 - heart rate at

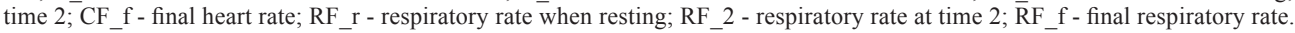

Table 2 - Experimental data - contextual variables

\begin{tabular}{|c|c|c|c|c|c|c|c|c|c|c|c|c|c|c|}
\hline \multirow{2}{*}{$\begin{array}{l}\text { Experimental } \\
\text { unit }\end{array}$} & \multirow{2}{*}{$\begin{array}{c}\text { Room } \\
\text { temperature }\left({ }^{\circ} \mathrm{C}\right)\end{array}$} & \multirow{2}{*}{$\begin{array}{l}\text { Horse weight } \\
\qquad(\mathrm{kg})\end{array}$} & \multirow{2}{*}{$\begin{array}{l}\text { Horse age } \\
\text { (years) }\end{array}$} & \multicolumn{11}{|c|}{ Horse superficial temperature $\left({ }^{\circ} \mathrm{C}\right)$} \\
\hline & & & & Tsg & Tsn & Tscx & Tsp & Tsc & Tspt & Tsa & Tsb & Tsj & Tsbp & Tspf \\
\hline $1 \mathrm{P}$ & 26.6 & 370 & 22 & 35.8 & 34.2 & 35.5 & 34.7 & 35.4 & 35.0 & 34.7 & 34.3 & 35.8 & 34.9 & 34.7 \\
\hline $2 \mathrm{P}$ & 23.8 & 360 & 14 & 32.1 & 34.7 & 35.2 & 34.5 & 32.8 & 35.7 & 34.3 & 33.7 & 34.1 & 35.2 & 34.9 \\
\hline $3 P$ & 26.6 & 385 & 15 & 36.3 & 34.4 & 37.4 & 35.6 & 37.0 & 34.7 & 35.4 & 35.8 & 36.9 & 35.5 & 35.3 \\
\hline $4 P$ & 29.0 & 355 & 14 & 33.6 & 34.8 & 35.3 & 35.5 & 33.5 & 33.2 & 33.7 & 34.0 & 33.2 & 33.2 & 36.0 \\
\hline $5 \mathrm{P}$ & 30.5 & 362 & 14 & 34.7 & 36.5 & 37.0 & 36.0 & 35.6 & 37.1 & 37.0 & 36.2 & 34.7 & 36.7 & 35.0 \\
\hline $6 \mathrm{P}$ & 30.2 & 390 & 16 & 33.2 & 34.6 & 35.1 & 34.5 & 34.1 & 34.9 & 35.7 & 35.0 & 35.0 & 34.6 & 36.6 \\
\hline $7 P$ & 33.6 & 359 & 15 & 39.3 & 39.7 & 38.5 & 39.1 & 38.6 & 37.6 & 37.8 & 37.9 & 37.4 & 37.3 & 37.5 \\
\hline $8 \mathrm{P}$ & 34.0 & 300 & 9 & 35.1 & 36.7 & 37.2 & 36.9 & 35.2 & 36.6 & 36.5 & 36.4 & 35.8 & 36.3 & 36.2 \\
\hline $1 \mathrm{~N}$ & 36.1 & 360 & 10 & 35.7 & 37.5 & 37.8 & 37.3 & 36.8 & 37.5 & 37.5 & 37.1 & 36.8 & 37.5 & 36.8 \\
\hline $2 \mathrm{~N}$ & 30.8 & 300 & 11 & 36.8 & 37.1 & 37.5 & 37.3 & 36.9 & 38.4 & 38.2 & 38.1 & 36.7 & 38.2 & 37.1 \\
\hline $3 \mathrm{~N}$ & 32.1 & 310 & 11 & 33.2 & 35.9 & 35.5 & 35.3 & 34.0 & 35.7 & 36.0 & 35.0 & 33.6 & 35.0 & 36.4 \\
\hline $4 \mathrm{~N}$ & 23.7 & 380 & 11 & 31.6 & 32.8 & 33.65 & 33.5 & 31.2 & 33.0 & 32.8 & 32.5 & 30.0 & 30.5 & 33.8 \\
\hline $5 \mathrm{~N}$ & 27.6 & 388 & 11 & 35.8 & 34.8 & 36.7 & 35.5 & 35.2 & 36.4 & 36.7 & 35.9 & 35.1 & 36.8 & 36.1 \\
\hline $6 \mathrm{~N}$ & 27.7 & 285 & 12 & 34.0 & 33.2 & 34.4 & 34.1 & 33.0 & 34.7 & 34.4 & 34.1 & 32.0 & 35.3 & 35.4 \\
\hline $7 \mathrm{~N}$ & 30.9 & 355 & 9 & 33.3 & 35.5 & 36.0 & 35.4 & 34.1 & 36.4 & 36.8 & 35.9 & 34.7 & 36.6 & 35.9 \\
\hline $8 \mathrm{~N}$ & 28.3 & 355 & - & 33.5 & 35.3 & 35.4 & 34.6 & 33.2 & 34.7 & 34.8 & 34.1 & 32.9 & 34.3 & 35.7 \\
\hline
\end{tabular}

Tsg - croup; Tsn - buttocks; Tscx - gaskin; Tsp - legs; Tsc - cannons; Tspt - chest; Tsa - forearms; Tsb - arms; Tsj - knees; Tspb - neck; Tspf - nose. 
assessment of treatment differences based on the output vector and unitary input. This is the approach suggested in Gomes et al. (2008).

Assuming unitary inputs is suitable for experimental design evaluation. Under this assumption, all experimental units are set on the same basis for comparisons. Therefore, the differences in the response vector are assumed to be due to error control variables (induced by the choice of the experimental design) and to the influence of contextual variables. These are qualitative or quantitative variables that affect the experimental units and which are under the control of the researcher. The effects of contextual variables are assessed in a second stage using a linear model and the DEA score as the response variable. In this context, we postulated the classical assumptions (Steel et al., 1996) of the analysis of variance (covariance).

The unitary input DEA model is presented in (2), in which $h_{o}$ is the performance score (efficiency) of the experimental unit $o$, with production values $\left(1, y_{o}\right)$. Each experimental unit $k, k=1 \ldots n$, produces $s$ outputs $y_{j k}, j=1 \ldots s$ (non-negative, not all zeros). The quantities $u_{j}$ are the most favorable weights attributable to the response vector to calculate the performance score.

$$
\begin{aligned}
& \operatorname{Max} h_{o}=\sum_{j=1}^{s} u_{j} y_{j o} \\
& \text { subject to } \\
& \sum_{i=1}^{r} v_{i}=1 \\
& \sum_{j=1}^{s} u_{j} y_{j k}-\sum_{i=1}^{r} v_{i} \leq 0, k=1, \ldots, n \\
& u_{j}, v_{i} \geq 0 \quad \forall j, i
\end{aligned}
$$

We observed here that it is not necessary to assume an underlying production function (frontier) as a datagenerating process for the output vector. We are interested here in a performance model instead of a production model. Data envelopment analysis also serves this purpose in general (Gomes et al., 2008; Cook et al., 2014). We assumed a data-generating process in which a population of DEA responses is determined by the experimental error, given that the values of covariates are fixed.

\section{Results}

The multivariate factor analysis for the performance indicators hematocrit, heart rate, respiratory rate, and superficial temperature of the horse (Table 3 ) indicated a one-factor model for each dimension (Table 4).

Scores of DEA and the corresponding weights assigned by the DEA model were computed in the optimal solution for each animal (Table 5). The average weights to be applied to each output variable were also determined (Table 5). The modified DEA score is a linear combination of the ranked output variables using these average weights, leading to the final performance scores and the corresponding rank transformation (Table 6).

Finally, we performed a nonparametric regression analysis of the final performance scores on the regressors treatment effect and room temperature (Table 7). The statistical model used is $R_{i j}=\mu+\tau_{i}+\beta t_{i j}+\varepsilon_{i j}, i=1,2$ $j=1, \ldots, 16$, in which $R_{i j}$ is the rank of the performance score of horse $j$ under treatment $i$, subject to rank of room temperature $t_{i j}$. The constants $\mu, \tau_{i}$, and $\beta$ are parameters to be estimated. Parameter $\mu$ is an overall mean, $\tau_{i}$ are treatment effects, and $\beta$ is the decrease in performance resulting from the increase in one unit

\begin{tabular}{|c|c|c|c|c|c|c|c|}
\hline \multicolumn{2}{|c|}{ Hematocrit } & \multicolumn{2}{|c|}{ Heart rate } & \multicolumn{2}{|c|}{ Respiratory rate } & \multicolumn{2}{|c|}{ Superficial temperature } \\
\hline Component & Communality & Component & Communality & Component & Communality & Component & Communality \\
\hline H_r & 0.3002 & $\mathrm{CF}_{-} \mathrm{r}$ & 0.1211 & RF_r & 0.4480 & Tsg & 0.7235 \\
\hline H_o & 0.6842 & $\mathrm{CF}_{-}^{-} 1$ & 0.0001 & RF_2 & 0.6620 & Tsn & 0.7967 \\
\hline H_10 & 0.7071 & CF_2 & 0.6939 & $\mathrm{RF}_{-} \mathrm{f}$ & 0.2373 & Tscx & 0.9118 \\
\hline H_30 & 0.8605 & $\mathrm{CF}_{-}^{-} \mathrm{f}$ & 0.5228 & & & Tsp & 0.8794 \\
\hline \multirow[t]{7}{*}{ H_60 } & 0.1280 & & & & & Tsc & 0.8714 \\
\hline & & & & & & Tspt & 0.7916 \\
\hline & & & & & & Tsa & 0.8816 \\
\hline & & & & & & Tsb & 0.9629 \\
\hline & & & & & & Tsj & 0.7888 \\
\hline & & & & & & Tsbp & 0.8017 \\
\hline & & & & & & Tspf & 0.6004 \\
\hline
\end{tabular}
of room temperature. The model does not include an interaction effect in room temperature. The error term $\varepsilon_{i j}$ may be neither normal nor homoscedastic.

Table 3 - Multivariate factor analysis for hematocrit, heart rate, respiratory rate, and animal superficial temperature

H_r - hematocrit when resting; H_0 - hematocrit immediately after the stress test; H_10 - hematocrit 10 min after the stress test; H_30 - hematocrit 30 min after the stress test; H 60 - hematocrit 60 min after the stress test; CF r - heart rate when resting; CF 1 - heart rate at time 1 ; CF 2 - heart rate at time 2 ; $\bar{C} F$ f - final heart rate; RF r - respiratory rate when resting; RF_2 - respiratory rate at time 2; $\bar{R} F \_$- final respiratory rate; Tsg - croup; Tsn - buttocks; Tscx - gaskin; Tsp - legs; Tsc - cannons; Tspt - chest; Tsa - forearms; Tsb - arms; Tsj - knees; Tspb - neck; Tspf - nose. 
Table 4 - Aggregate scores

\begin{tabular}{lcccc}
\hline $\begin{array}{l}\text { Experimental } \\
\text { unit }\end{array}$ & $\begin{array}{c}\text { Hematocrit } \\
\text { score }(\%)\end{array}$ & $\begin{array}{c}\text { Heart rate score } \\
\text { (beats per } \\
\text { minute) }\end{array}$ & $\begin{array}{c}\text { Respiratory } \\
\text { rate score } \\
\text { (breaths per } \\
\text { minute) }\end{array}$ & $\begin{array}{c}\text { Superficial } \\
\text { temperature } \\
\text { score }\left({ }^{\circ} \mathrm{C}\right)\end{array}$ \\
\hline $1 \mathrm{P}$ & 36.0748 & 167.8530 & 30.4847 & 34.991 \\
$2 \mathrm{P}$ & 36.1248 & 161.0071 & 47.0040 & 34.286 \\
$3 \mathrm{P}$ & 24.9302 & 159.8582 & 42.6989 & 35.875 \\
$4 \mathrm{P}$ & 29.7957 & 122.6627 & 43.5510 & 34.161 \\
$5 \mathrm{P}$ & 31.2093 & 161.3870 & 40.9012 & 36.100 \\
$6 \mathrm{P}$ & 34.4997 & 187.7760 & 44.0290 & 34.825 \\
$7 \mathrm{P}$ & 27.2426 & 183.3190 & 53.3591 & 38.257 \\
$8 \mathrm{P}$ & 31.3095 & 155.3134 & 47.3543 & 36.288 \\
$1 \mathrm{~N}$ & 33.4243 & 135.3044 & 60.0097 & 37.148 \\
$2 \mathrm{~N}$ & 33.4066 & 166.4014 & 77.9254 & 37.508 \\
$3 \mathrm{~N}$ & 32.3367 & 195.3226 & 63.3342 & 35.048 \\
$4 \mathrm{~N}$ & 33.0279 & 122.5718 & 45.3518 & 32.306 \\
$5 \mathrm{~N}$ & 38.1525 & 161.3432 & 48.5092 & 35.914 \\
$6 \mathrm{~N}$ & 38.5050 & 190.4081 & 49.3591 & 34.028 \\
$7 \mathrm{~N}$ & 33.1840 & 121.8469 & 62.5511 & 35.532 \\
$8 \mathrm{~N}$ & 33.4251 & 151.1256 & 56.2458 & 34.392 \\
\hline
\end{tabular}

Table 5 - Data envelopment analysis (DEA) scores and output weights

\begin{tabular}{lccccc}
\hline \multirow{2}{*}{$\begin{array}{l}\text { Experimental } \\
\text { unit }\end{array}$} & $\begin{array}{c}\text { DEA } \\
\text { score }\end{array}$ & $\begin{array}{c}\text { Lactic } \\
\text { acid }\end{array}$ & Distance & $\begin{array}{c}\text { Hematocrit } \\
\text { score }\end{array}$ & $\begin{array}{c}\text { Respiratory } \\
\text { rate score }\end{array}$ \\
\hline $1 \mathrm{P}$ & 0.8751 & 0.0157 & 0.1505 & 0.0059 & 0.0000 \\
$2 \mathrm{P}$ & 1.0000 & 0.0137 & 0.1317 & 0.0052 & 0.0000 \\
$3 \mathrm{P}$ & 0.5857 & 0.0244 & 0.2439 & 0.0000 & 0.0000 \\
$4 \mathrm{P}$ & 1.0000 & 0.0180 & 0.1439 & 0.0000 & 0.0000 \\
$5 \mathrm{P}$ & 0.9144 & 0.0187 & 0.1498 & 0.0000 & 0.0000 \\
$6 \mathrm{P}$ & 0.7500 & 0.0000 & 0.0000 & 0.0833 & 0.0000 \\
$7 \mathrm{P}$ & 0.7068 & 0.0000 & 0.1064 & 0.0000 & 0.0532 \\
$8 \mathrm{P}$ & 0.6277 & 0.0000 & 0.1863 & 0.0000 & 0.0342 \\
$1 \mathrm{~N}$ & 0.9096 & 0.0000 & 0.0000 & 0.0397 & 0.0464 \\
$2 \mathrm{~N}$ & 1.0000 & 0.0625 & 0.0000 & 0.0000 & 0.0000 \\
$3 \mathrm{~N}$ & 1.0000 & 0.0000 & 0.0752 & 0.0000 & 0.0376 \\
$4 \mathrm{~N}$ & 0.9143 & 0.0156 & 0.1563 & 0.0000 & 0.0000 \\
$5 \mathrm{~N}$ & 1.0000 & 0.0000 & 0.0340 & 0.0510 & 0.0000 \\
$6 \mathrm{~N}$ & 1.0000 & 0.0000 & 0.0000 & 0.0625 & 0.0000 \\
$7 \mathrm{~N}$ & 0.9630 & 0.0144 & 0.1382 & 0.0028 & 0.0032 \\
$8 \mathrm{~N}$ & 0.9362 & 0.0148 & 0.1421 & 0.0029 & 0.0033 \\
$\mathrm{Mean}$ & & 0.0124 & 0.1037 & 0.0158 & 0.0111 \\
\hline
\end{tabular}

Table 6 - Final performance scores

\begin{tabular}{lcc}
\hline Experimental unit & $\begin{array}{c}\text { Final performance score (values } \\
\text { normalized by the maximum) }\end{array}$ & $\begin{array}{c}\text { Rank of the final } \\
\text { performance score }\end{array}$ \\
\hline $1 \mathrm{P}$ & 0.5702 & 8 \\
$2 \mathrm{P}$ & 0.9849 & 15 \\
$3 \mathrm{P}$ & 0.1400 & 1 \\
$4 \mathrm{P}$ & 0.4417 & 5 \\
$5 \mathrm{P}$ & 0.5233 & 7 \\
$6 \mathrm{P}$ & 0.3595 & 4 \\
$7 \mathrm{P}$ & 0.1983 & 2 \\
$8 \mathrm{P}$ & 0.2115 & 3 \\
$1 \mathrm{~N}$ & 0.4519 & 6 \\
$2 \mathrm{~N}$ & 0.6709 & 9 \\
$3 \mathrm{~N}$ & 0.9010 & 14 \\
$4 \mathrm{~N}$ & 0.8221 & 12 \\
$5 \mathrm{~N}$ & 1.0000 & 16 \\
$6 \mathrm{~N}$ & 0.8158 & 11 \\
$7 \mathrm{~N}$ & 0.7625 & 10 \\
$8 \mathrm{~N}$ & 0.8279 & 13 \\
\hline
\end{tabular}

Table 7 - Nonparametric regression - bootstrap replications

\begin{tabular}{lrrrrr}
\hline & Coefficient & Bias & $\begin{array}{c}\text { Bootstrap } \\
\text { standard } \\
\text { error }\end{array}$ & $\begin{array}{c}\text { Bias-corrected 95\% } \\
\text { confidence interval }\end{array}$ \\
\hline Treatment effect & 6.0764 & 1.0000 & 1.5340 & 2.9489 & 8.9710 \\
Room temperature & -0.4351 & 0.0073 & 0.2026 & -0.8307 & -0.0253 \\
Constant & 9.1605 & -0.1399 & 2.6542 & 3.7820 & 13.9987 \\
\hline
\end{tabular}

\section{Discussion}

Regarding the multivariate factor analysis, the hematocrit indicator had five components, heart rate had four, respiratory rate had three, and superficial temperature had 11 components. The likelihood ratio tests of orthogonality produced the statistics $43.05(\mathrm{P}<0.001)$, $13.23(\mathrm{P}=0.0395), 11.45(\mathrm{P}=0.0095)$, and 286.89 $(\mathrm{P}<0.0001)$ for the hematocrit, heart rate, respiratory rate, and superficial temperature, respectively. Under the null hypothesis of independence (non-factor model), the distributions are chi-square with 10, 6, 3, and 55 degrees of freedom, respectively. These statistical tests support the factor model. Models with more than one factor did not converge under maximum likelihood estimation. Therefore, we used the minimum eigenvalue equal to 1 as the choice criterion of the number of factors, which leads to one factor in all cases, implying average aggregated scores calculated using the relative communalities as weights (Table 4).

The performance vector, that is, the output variables for the DEA model, is defined by distance achieved, lactic acid blood concentration, hematocrit score, heart rate score, and respiratory rate score. It is important to emphasize here that these data were ranked before undergoing the DEA analysis.

We performed a multivariate analysis of variance using the ranked output variables as dependent variables. The independent variables were treatment (positive and negative for EIA), ranked room temperature, ranked animal weight, ranked animal age, and ranked animal superficial temperature score. Wilks' lambda test of treatment effect was not significant. In this context, DEA provides a better insight into the performance issue, discriminating the responses for treatments.

The output variables were subjected to a screening process before applying DEA. The very nature of DEA precludes negative correlations between the final performance achieved and the output components. This was the case with heart rate in our application, showing a rank correlation of -0.326 with the distance and low correlations with the hematocrit score, respiratory rate, and lactic acid concentration. For this reason, we opted to eliminate heart rate and use a four-dimensional output in the DEA model. 
From the DEA results (Table 5), we understand that a null weight for a variable such as distance achieved is not acceptable in the calculation of a global performance score. An alternative within DEA models to avoid this drawback is to impose restrictions on the weights (Thanassoulis et al., 2004). Typically, these are achieved by introducing preferences (by means of value judgments) on the relative worth of the variables. We believe that a better approach in our case is to use average weights for each variable. The weights are normalized means of individual DEA solutions. Thus, our final performance scores were weighted averages of rank-transformed values (Table 6).

The box plots for rank-transformed final efficiency score by treatment effect (Figure 1) indicate a reduction of more than $60 \%$ in performance from negative EIA (11.5) to positive EIA (4.5) horses, measured by unadjusted (for covariates) median responses. The five-number summaries are: positive EIA - minimum $=1.0, \mathrm{Q} 1=2.5$, median $=4.5$,

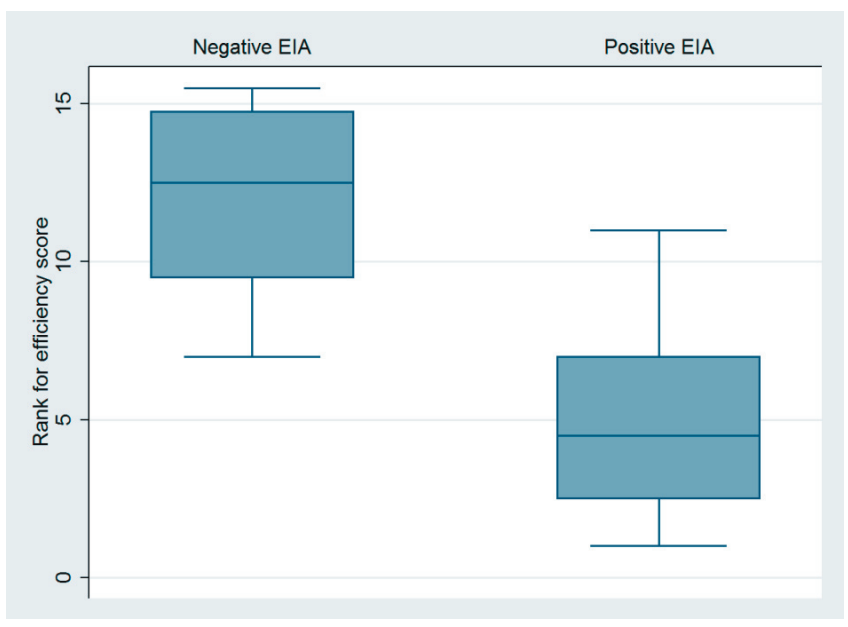

Figure 1 - Box plots: efficiency scores by treatments.

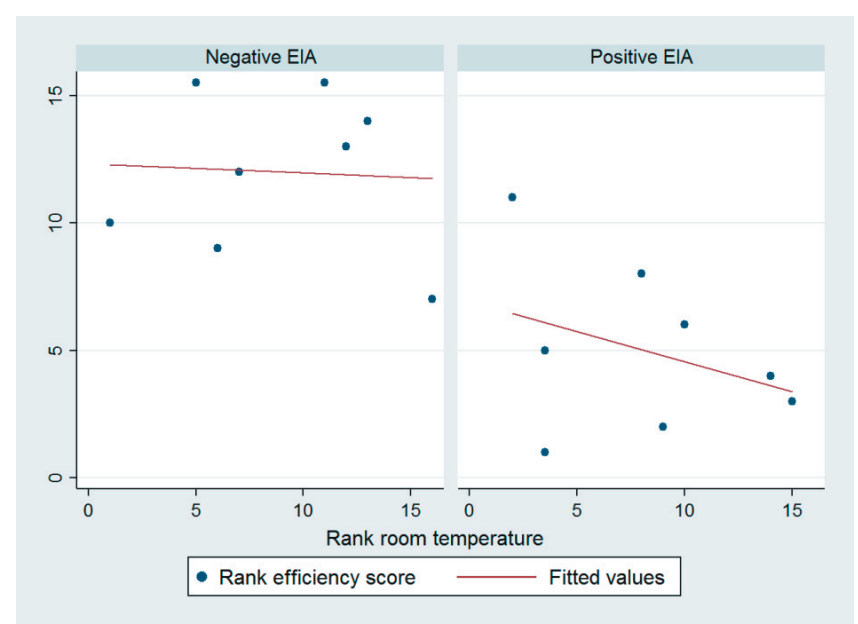

Figure 2 - Efficiency scores versus room temperature by treatment.
$\mathrm{Q} 3=7.5$, maximum $=15.0$; negative EIA - minimum $=6.0$, $\mathrm{Q} 1=9.5$, median $=11.5, \mathrm{Q} 3=13.5$, maximum $=16.0$.

All covariates correlated negatively with the performance score. Together, they did not lead to a significant model. Included one at a time, they produced significant treatment effects and P-values of 0.0819, 0.6247, 0.6336, and 0.0320 for animal superficial temperature, animal weight, animal age, and room temperature, respectively. Including room temperature in the model was enough. The addition of any other covariate combinations was not statistically significant. Thus, the best parsimonious model used treatment and room temperature as covariates.

The behavior of the efficiency scores as a function of room temperature suggests a negative effect for both treatments (Figure 2), more intense for the positive EIA horses. The difference in slopes (Figure 2) was not sufficient to declare an interaction effect. Correlations induced by the computations among final performance scores of animals were handled by a nonparametric bootstrap (Table 7). We performed 2,000 replications using Stata 14.1 (Stata, 2015).

The main point we emphasize (Table 7) is the EIA effect on performance adjusted by room temperature. We assessed this effect using the intercepts in the cases of positive and negative EIA . The relative reduction in performance was, therefore, $6.0764 / 15.2369=39.9 \%$.

\section{Conclusions}

Animal age, animal weight, and animal superficial temperature do not significantly affect the performance score. Given that room temperature and treatment have been fitted, these covariates do not increase model significance. There is a significant treatment effect and a significant negative slope regression coefficient for room temperature. Adjusted for room temperature, there is a decrease of almost $40 \%$ in performance of positive EIA horses compared with horses testing negative for EIA. Therefore, the control of this disease in the Pantanal wetlands is of importance, as it may reduce the performance of the horses, considering the functional conditions of cattle management.

\section{Acknowledgments}

We thank Reinaldo Melillo Filho, Marcílio Brito, Pietro Holtz, Henrique de Jesus, and employees of the farms for their assistance during the performance tests of horses. We also thank Luciano de Barros for yielding farms and horses for the experiment. We also acknowledge the financial 
supports of Empresa Brasileira de Pesquisa Agropecuária (Embrapa), Conselho Nacional de Desenvolvimento Científico e Tecnológico (CNPq), Fundação de Apoio à Pesquisa do Estado de Minas Gerais (FAPEMIG), and Coordenadoria de Apoio à Pesquisa (CAPES).

\section{References}

Bezerra Neto, F.; Gomes, E. G. and Oliveira, A. M. 2007. Produtividade biológica em sistemas consorciados de cenoura e alface avaliada através de indicadores agroeconômicos e métodos multicritério. Horticultura Brasileira 25:193-198.

Bezerra Neto, F.; Gomes, E. G.; Araujo, R. R.; Oliveira, E. Q.; Nunes, G. H. S.; Grangeiro, L. C. and Azevedo, C. M. S. B. 2010. Evaluation of yield advantage indexes in carrot-lettuce intercropping systems. Interciencia 35:59-64.

Bezerra Neto, F.; Porto, V. C. N.; Gomes, E. G.; Cecilio Filho, A. B. and Moreira, J. N. 2012. Assessment of agroeconomic indices in polycultures of lettuce, rocket and carrot through uni- and multivariate approaches in semi-arid Brazil. Ecological Indicators 14:11-17.

Brasil. 2004. Instrução Normativa $N^{\circ} 45$, de 15 de junho de 2004, da Secretaria de Defesa Agropecuária do Ministério da Agricultura, Pecuária e Abastecimento. Available at: < http://www.idaron. ro.gov.br/portal/legislacao/arquivos/exibir.ashx?arquivo=145\&es pecie $=$ Instrucao_Normativa\&Num $=45 \&$ ano $=2004>$. Accessed on: Sept. 10, 2014.

Caporaletti, L. E.; Dulá, J. H. and Womer, N. K. 1999. Performance evaluation based on multiple attributes with nonparametric frontiers. Omega 27:637-645.

Cook, R. F.; Cook, S. J. and Issel, C. J. 2009. Equine Infectious Anemia. p.56-71. In: Infectious diseases of the horse. Mair, T. S. and Hutchinson, R. E., eds, Fordham, UK.

Cook, W. D.; Tone, K.; Zhu, J. 2014. Data envelopment analysis: Prior to choosing a model. Omega 44:1-4.

Cooper, W. W.; Seiford, L. M. and Zhu, J. 2011. Handbook on data envelopment analysis. 2nd ed. Springer, New York.

Craigo, J. K. and Montelaro, R. C. 2008. Equine infectious anemia virus. Encyclopedia of Virology 2:167-174.

De Koeijer, T. J.; Wossink, G. A. A.; Struik, P. C. and Renkema, J. A. 2002. Measuring agricultural sustainability in terms of efficiency: the case of Dutch sugar beet growers. Journal of Environmental Management 66:9-17.

Gomes, E. G.; Abreu, U. G. P.; Soares de Mello, J. C. C. B.; Carvalho, T. B. and Zen, S. 2012. Unitary input DEA model to identify beef cattle production systems typologies. Pesquisa Operacional 32:389-406.

Gomes, E. G.; Souza, G. S. and Vivaldi, L. J. 2008. Two-stage inference in experimental design using DEA: an application to intercropping and evidence from randomization theory. Pesquisa Operacional 28:339-354.

Grigoroudis, E.; Petridis, K. and Arabatzis, G. 2014. RDEA: A recursive DEA based algorithm for the optimal design of biomass supply chain networks. Renewable Energy 71:113-122.

Gutiérrez, E. and Lozano, S. 2010. Data envelopment analysis of multiple response experiments. Applied Mathematical Modelling 34:1139-1148.

Johnson, R. A. and Wichern, D. W. 2007. Applied multivariate statistical analysis. 6th ed. Pearson, New Jersey.
Juliano, R. S.; Santos, C. E. P. and Batista, F. A. 2016. Manejo sanitário de equinos. p.417-445. In: Cavalo Pantaneiro: rústico por natureza, Santos, S. A.; Salis, S. M. and Comastri Filho, J. A., eds, Embrapa Informação Tecnológica, Brasília.

Leme, R. C.; Paiva, A. P.; Steele Santos, P. E.; Balestrassi, P. P. and Galvão, L. D. L. 2014. Design of experiments applied to environmental variables analysis in electricity utilities efficiency: The Brazilian case. Energy Economics 45:111-119.

Leta, F. R.; Soares de Mello, J. C. C. B.; Gomes, E. G. and Angulo Meza, L. 2005. Métodos de melhora de ordenação em DEA aplicados à avaliação estática de tornos mecânicos. Investigação Operacional 25:229-242.

Lima, J. S. S.; Bezerra Neto, F.; Gomes, E. G.; Negreiros, M. Z.; Pontes, F. S. T.; Medeiros, M. A. and Barros Júnior, A. P. 2014. Agroeconomic evaluation of intercropping rocket and carrot by uni- and multivariate analyses in a semi-arid region of Brazil. Ecological Indicators 41:109-114.

Liu, C.-M. and Yang, C.-Y. 2014. Robust design for activated carbon filters. Journal of Quality 21:329-348.

Lovell, C. A. K. and Pastor, J. T. 1999. Radial DEA models without inputs or without outputs. European Journal of Operational Research 18:46-51.

Mardia, K. V.; Kent, J. T. and Bibby, J. M. 1980. Multivariate analysis. Academic Press, New York.

Marlin, B. and Sohn, H. 2016. Using DEA in conjunction with designs of experiments: An approach to assess simulated futures in the Afghan educational system. Journal of Simulation 10:272-282.

Miranda, R. D. C.; Montevechi, J. A. B.; da Silva, A. F. and Marins, F. A. S. 2017. Increasing the efficiency in integer simulation optimization: Reducing the search space through data envelopment analysis and orthogonal arrays. European Journal of Operational Research 262:673-681.

Oliveira, A. L. C.; Montezuma, E. E.; Ravaglia, E.; Juliano, R. S. and Nogueira, M. F. 2011. Avaliação da prevenção e controle da enemia infecciosa equina no Pantanal. Embrapa Pantanal, Corumbá. Available at: <http://www.cpap.embrapa.br/publicaoes/ online/CT98.pdf $>$. Accessed on: June 22, 2017.

Rezende, A. S. C.; Santos, D. R.; Santos, S. A.; Lima, M. F. N. T.; Santiago, J. M.; Mellito Filho, R.; Barcelos, K. M. and Trigo, P. 2016. A anemia infecciosa equina afeta o desempenho funcional dos equinos no Pantanal matogrossense? In: Actas de La Conferencia Internacional de CAballos de DEporte - CICADE, Ribeirão Preto.

Santos, S. A.; Salis, S. M. and Comastri Filho, J. A. 2016. Cavalo Pantaneiro: rústico por natureza. Embrapa Informação Tecnológica, Brasília.

Scheffé, H. 1959. The analysis of variance. Wiley, New York.

Stata. 2015. Base reference manual release 14. Stata Press, Texas.

Steel, R. G. D.; Torrie, J. H. and Dickey, D. A. 1996. Principles and procedures of statistics: A biometrical approach. McGraw-Hill, New York.

Thanassoulis, E.; Portela, M. C. A. S. and Allen, R. 2004. Incorporating value judgments in DEA. p.99-138. In: Handbook on data envelopment analysis. Cooper. W. W.; Seiford, L. W. and Zhu, J., eds. Kluwer Academic Publishers, Boston.

Yang, C.-Y.; Dai, C.; Yi, X.; Lu, W.-T. and Guo, H.-C. 2016. Total emission control of water pollutant for the lake basin based on orthogonal experimental design and EFDC Model: A case study of Dianchi Basin. Zhongguo Huanjing Kexue/China Environmental Science 36:3696-3702. 